\title{
Surveillance \& Society Disappearing Citizenship: surveillance and the state of exception
}

\section{Jeremy Douglas}

Independent Scholar. mailto:jerdouglas@yahoo.co.uk

\begin{abstract}
Surveillance is an ancient concept and an ancient practice. As such, we must undertake a theoretical examination of surveillance that looks at the changes in the function of surveillance within a juridical-political model, rather than superficially studying the nature of surveillance mechanisms. What emerges is a surveillance system that is fundamentally biopolitical and is in many ways - as a defining 'modern' characteristic - the reason for a permanent state of exception and the loss of rights and citizenship.
\end{abstract}

\section{Introduction - The Ancient Judean Camp}

In 6CE, the Roman Empire's client Kingdom of Judea became a Roman province, raising political and religious tensions between the Jews and the new Roman rulers. The Jews revolted against the Romans in 66CE, in what is known as the Great Jewish Revolt, in order to gain political and religious independence from Rome. However, this revolt was crushed by some 60,000 Roman soldiers, and came to a bloody end in 68CE. In the following years the rebellious territory was reconquered, many Jews crucified, Jewish temples burned, and Jerusalem invaded and almost completely destroyed. Sixty years later the Jews revolted again, in an attack led by the Nasi Israel (ruler of Israel) Simon Bar Kokhba, after whom the revolt was named. Again, this Jewish uprising was crushed in the year 135CE, though not without significant Roman losses. As with the first revolt, the Jews fled to the Judean Desert with the Romans following, imprisoning, and executing them. The west bank of the Dead Sea, including Massada and surrounding areas, became a respite for fleeing Jews. As the Romans located and imprisoned the Jews that had gone into hiding in the caves and canyons, they began urbanizing Judea with a series of roads, quarries, and buildings - the work being carried out by Jewish prisoners as well as Roman soldiers (Yekutieli 2006, 71-2).

One particular Jewish work camp in the Judea Desert, occupied and run by the Romans, was actually a complex of pre-existing structures from the Hellenistic and Islamic periods. The site consists of one large watchtower structure and two smaller structures downhill from the watchtower. The layout of this Hellenistic site functioned as an ideal work camp quarry for the Romans, although it had originally been constructed as an Islamic burial ground and temporary shelter for travellers. A recent excavation of the camp (Yekutieli et al. 2006) revealed a number of potsherds and heaths that were carbon-dated to the first and second century CE. Some of these remains were found along the slope of the tower, which contained a number of small $(1 \mathrm{x} 2 \mathrm{~m})$ rock shelters, while other remains were discovered on the summit of the tower, which, through a crevice, looks down over the slope and the other structures; these findings reveal that people were living in the shelters as well as at the summit. What is unique about this camp is the way in which the territory is manipulated in order to allow for the surveillance of the workers. From the lookout 
crevice at the top of the tower, one can see the entire landscape, including the quarry, workers' shelters, cooking areas, etc., without being seen by anyone in those locations. Further, the layout of the shelters on the slope allowed one to see no more than two other shelters at a time (ibid, 76). From these observations, we can see that the architecture of the camp was designed so as to allow for a panoptic power structure in which the Romans could achieve the subjectivization of the detainees though their awareness of a potential observer.

This type of structure, which allows for an unseen seer to watch over individuals occupying a given territory, is nothing new - in fact, such surveillance structures have been recorded from as far back as the Early Bronze Age (3000-2650 BC) (ibid, 78-85). However, these earlier surveillance systems were used in order to guard a territory against an attack, as with the lookout towers constructed at the top of castles. What distinguishes the Roman work camp from other ancient surveillance mechanisms is the way in which is it integrated into, and in many ways the precondition for, the political structure that creates the camp. The encampment of rebellious Jews characterizes the state of emergency, in which 'normal' law is suspended in order to use any means necessary to protect the interest of the sovereign. Thus, the Jews in the camp must be removed from the political realm and treated as bare life that must be constantly monitored and exposed to the potentiality of violence. As we shall see, this camp serves a paradigmatic example of affects of surveillance, insofar as it is the amalgamation of the state of exception, bare life, violence, law, biopolitics, territory, and governmentality; not to mention that evidence of surveillance and camp structures that existed thousands of years ago demonstrates that none of these concepts are new and modern phenomena. Governmentality is able to function as the control of the population and the creation of bare life because it employs surveillance as a crucial tactic in the management of life - this is clearly presented in the Roman camp example.

However, although many of the concepts and techniques we see at work in the camp are not fundamentally different today, not everything has remained the same. The importance of a juridicalpolitical system that acts according to the state of exception, or suspension of the law, is evident in the emergence of recent totalitarian and 'democratic' permanent states of emergency; for example, the UK and the US have normalised the exception through the passing of 'laws' (Terrorism Act, Patriot Act, etc.) that essentially nullify the application of normal laws protecting human rights, while still holding them technically 'in force'. We see also that these 'exceptional' laws go hand in hand with increased surveillance, both of which are tactics that establish control of the population. Yet what remains to be analysed is the relation(s) between surveillance, territory, and the state of exception - how does surveillance allow for the rise of the state of exception and the camp? And, more broadly, how are all there concepts integrated in an art of government? Surveillance must be regarded as the point at which the camp and the bare of the state of exception intersect in the governmental control of the population.

\section{Defining the Terms: Foucault and Agamben}

Although Michel Foucault wrote a book (Discipline and Punish) that dealt extensively with one method of surveillance, the panoptic, his more useful contribution to the theory of surveillance comes from his study of 'governmentality', or the 'art' of governing. In the course of his 1970s lectures at the College de France, Foucault underwent a significant shift in the emphasis of his theory, moving from the powerterritory relationship of sovereignty to the politico-economic governmentality of population; the concept of sovereignty concerned with maintaining power and territory is a dated pre-modern concept, and what needs to be analysed now is the governing of a population though various circulatory (that is, relational) mechanisms: "it is not expanse of land that contributes to the greatness of the state, but fertility and the number of men" (Fleury quoted in Foucault 2007, 323). In other words, what is emerging in Foucault's writings, beginning with The History of Sexuality $\mathrm{Vol}$ 1, is the concept of biopolitics: "the management of life rather than the menace of death” (Foucault 1990, 143).

Broadly, what is taking place in Foucault's works and lectures in the mid to late 1970s is his description of the differences (not transitions) between "sovereignty, discipline, and governmental 
management" (Foucault 2007, 107). The essential goal of sovereignty is to maintain power, which is achieved when laws are obeyed and the divine right of the throne is reaffirmed. 'Power' is the essential defining component of sovereignty, while 'government' is more or less just an administrative component within the sovereign state - a component that is the function of the family; the family, oikos, in ancient Greece was the private management (government) of economic matters where the father ensured the security, health, wealth, and goods of his wife and children, while the polis was the public realm where man realised his political significance in striving for "the good life". The rise of government in the sixteenth century is marked by this family government model being "applied to the state as a whole" (ibid, 93), as well as by the rise of "mercantilism" - the former not realizing its full scope and application until the eighteenth century and the latter being a stage of rasion d'état between sovereignty and governmentality. However, when the art of governing becomes the predominant 'goal' of the state in the eighteenth century, the family is relegated to the position of an "instrument" and population emerges as the "main target" (ibid, 108) of the government (territory is the main target of sovereignty insofar as a sovereign defines itself according to its territory, while government defines itself in term of its population). With population as the central concern for government, other institutions and sites - such as territory, the family, security (military), police, and discipline - all become "elements" or "instruments" in the management of the population - these biopolitical tactics are what primarily distinguish governmentality from sovereignty.

\section{Conduct and Subjectivization}

Foucault wants to situate bio-power in the multiplicity of relations within the overarching structure of the state, and therefore not discard the notion of 'power' but instead couch it in terms of governmentality. Biopolitics is produced in the relations between biological life and political power (bio-power), which is possible when a population is confronted with and in relation to the biopoliticizing (not to be confused with disciplining) techniques of institutions, territory, police, security, and surveillance; rather than positing a sovereign-people dialectic (which Agamben tends to do), Foucault wants to complicate the notion of biopolitics by accounting for a state that "spreads it tentacles" (Virilio 1997, 12) through its various instruments and tactics. It seems as though, with the beginning of a governmentality discourse developing in the Security, Territory, Population course, Foucault feels he has said enough about biopolitics as such and can now move towards the art and techniques of governmental and subjective "conduct", in which biopolitics is implicit.

Yet what emerges is, on the one hand, a theory of the top-down management of a population that is controlled through governmental mechanisms such as statistics-guided surveillance and police practices, and, on the other hand, the bottom-up subjectivization of population through the regulation of actions confronted with state power relations; this may also be regarded as biopolitical population control and individualizing discipline, respectively. These two streams of governmentality surface in Foucault's later writings from time to time, but he never clearly reconciles the art of government and subjectivization.

This subjective 'conduct' or 'governing the self' is a self-disciplining that is made possible through the knowledge of oneself as 'the other', as the object of an unseen seer (as is discussed with the panoptic model in Discipline and Punish). This self-conduct, however, is framed in terms of the problematic of government that uses the power relation techniques of governing others to govern themselves (Foucault 2000, 340-342); but again, where do these two points converge and differ? It seems as though we must look to surveillance to answer this question. We know that surveillance is certainly a governmental 'technique' for the management and control of the population, but we also see that subjectivization is only possible via surveillance, as just mentioned with the panoptic model. However, panoptic surveillance is an ancient notion, developed at least as far back as EBII, sometime around 3000-2650BC (Yekutieli 2006, 78). The relation between the seer and the subject is no longer that of a physical perspective from a point fixe, nor is it localised in a contained space, as with Bentham's prison model. Rather, as Paul Virilio would argue, surveillance is making the traditionally confined space of the camp the very centre of the city. However, before examining the juridical-political applications of this notion, we must 
understand Giorgio Agamben's conception of biopolitics in terms of "bare life" and "the state of exception”.

\section{Redefining Biopolitics}

Following and 'completing' Foucault's discussion of biopolitics, Agamben seeks to further explore the relation between state power and life, not in terms of governmentality, but rather, in terms of sovereign power. That is, what affect(s) does the state have upon the lives of citizens in relations of power and control? In a sense, Agamben's position is formulated in accordance with what Arendt and Foucault failed to do: Agamben completes Arendt's discussion of totalitarian power, "in which a biopolitical perspective is altogether lacking” (Agamben 1998, 4), and completes Foucault's discussion of biopolitics, which fails to address the most paradigmatic examples of modern biopolitics, such totalitarianism and the camp. This revision of Arendt and Foucault is achieved through the exemplification of the state of exception and bare life, which find their ultimate realization in modern examples of the camp. But first, it is necessary to understand how Agamben arrives at this conclusion.

In Politics, Aristotle distinguishes between natural, simple life ${ }^{1}$, Zoë, and political life, bios. Zoe is private life confined to the home, oikos, while bios is life that exists in the public (political) realm of the city, the polis; the former is life regulated by the economy of the family, while the latter is "good life" regulated by the state. It appears, then, that Zoë and bios are mutually exclusive, and man moves from an animal life to a distinct political life, as Aristotle seems to argue. Foucault picks up on this Aristotelian animal/political life when he writes of the "threshold of biological modernity" (Foucault 1990, 143), in The History of Sexuality, and modifies it to reflect the transition from a politics of the power-limit of death to the politicization of biological (or, more accurately, zoological - i.e. Zoë-logical) life: "For millennia, man remained what he was for Aristotle: a living animal [Zö̈] with the additional capacity for a political existence [bios]; modern man is an animal whose politics places his existence as a living being in question" (ibid). The distinction between Zoë and bios is called into question; what were once two distinct forms of life are now indistinguishable - biology has become political and politics has become biological, giving rise to biopolitics.

Agamben's claim, however, is that Foucault, Arendt, and others have misread Aristotle; in interpreting Aristotle, they believe that "the human capacity for political organization is not only different from but stands in direct opposition to that natural association whose center is the home (oikia) and the family" (Arendt 1998, 24, author's italics). On the contrary, the simultaneous inclusion and exclusion of life in politics - that is, the production of a biopolitcal life - is the "original activity of sovereign power" (Agamben 1998, 6). Although Aristotle appears to present zoe and bios as polar forms of life animal versus political - he provides indications that the supposed exclusion of natural life from the political realm is at the same time its inclusion, and therefore the originary biopolitical act: "we may say that while [the polis] grows for the sake of mere life, it exists for the sake of a good life" (Aristotle quoted in Politics, Metaphysics, and Death, 3). This implies, as Agamben notes, that natural life had to "transform" itself into political life; political life is not "in direct opposition" to natural life, then, but is born of it. The very notion of bios is itself only possible through its inclusion of zoe - "Nation-state means a state that makes nativity or birth (that is, naked human life) the foundation of its own sovereignty" (Agamben 1998, 20); biopolitics is this indistinction between private life and public life, an "undecidability... between life and law" (Agamben 2005, 86).

\section{Bare Life and the State of Exception}

This conception of biopolitics as an ancient and founding notion of sovereignty needs to be distinguished from what Agamben terms "bare life" or "homo sacer" (life that may be killed but not sacrificed). Biopolitical life, as mentioned above, is still within the juridical-political realm, but bare life is that which

\footnotetext{
${ }^{1}$ Agamben calls this 'naked' life in a number of places, but this can be confusing because he also uses the term 'bare life', which, although it seems similar to naked life, is something completely different - this is most likely a result of different translators of Agamben's works. So, I will call this 'naked' life by the name of 'natural' life.
} 
is banished from the polis. It is not pure political life as such, but a life that exists at the threshold between zoe and bios. Bare life is the indistinguishability between natural life and political life - a life that exists neither for the sake of politics nor for the sake of life: "bare life...dwells in the no-man's-land between the home and the city" (Agamben 1998, 90). It is a life that is banished from politics - outside of law - but included in its exclusion - still within the 'force of law':

The ban is essentially the power of delivering something over to itself, which is to say, the power of maintaining itself in relation to something presupposed as nonrelational [i.e. bare life]. What has been banned is delivered over to its own separateness and, at the same time, consigned to the mercy of the one who abandons it - at once excluded and included, removed and at the same time captured. (ibid, 110)

How is this possible? How can bare life be excluded and included? What implications would this have?

In order to understand how bare life is produced and how it can exists both within and outside of the polis, it is necessary to introduce another concept: state of exception. This notion is derived, by in large, from Carl Schmitt's book Political Theology, as well as from a fairly extensive debate between Walter Benjamin and Schmitt concerning the nature of the state of exception. The state of exception is a "suspension of law", which is usually instituted during a period of war or another state of emergency: "The exception, which is not codified in the existing legal order, can at best be characterized as a case of extreme peril, a danger to the existence of the state, or the like" (Schmitt 1922, 6). Under the state of exception there becomes a 'threshold' between law that is in the norm but is suspended and law that is not the norm - i.e. not necessarily part of the juridical order - but is in force; so, in the state of exception there appears this "ambiguous and uncertain zone in which de facto proceedings, which are themselves extra- or antijuridical, pass over into law, and juridical norms blur with the mere fact - that is, a threshold where fact and law seem to become undecidable" (Agamben 2005, 29). What needs to be underlined here is the relation between the state of exception and bare life. This point is absolutely crucial for Agamben and for understanding the role of governmental surveillance: the state of exception opens up the possibility of bare life and of the camp, where bare life is outside law but constantly exposed to violence and "unsanctionable killing” (Agamben 1994, 82). Agamben's position can be understood in the triadic relation 'state of exception-camp-bare life'; the ultimate power of the sovereign, and the complete dissolution of democracy into totalitarianism - two political systems that, according to Agamben, already have an "inner solidarity" (ibid, 10) - happens at the point when the state of exception becomes the rule and the camp emerges as the permanent realization of the indistinguishability between violence and law, to which we all, as homines sacri, are exposed. The paradigmatic example is, of course, Nazi Germany; but what remains to be seen is how this triad can be applied to our current political milieu.

\section{The Potentiality of/for Violence}

Perhaps the closest Agamben comes to discussing the relations between the state of exception and surveillance is his $11^{\text {th }}$ January 2004 article in Le Monde, entitled, "No to Bio-Political Tattooing” (Agamben, 2004). This article comes as a result of Agamben's cancellation of a course he was scheduled to teach at New York University that March. The reason he cancelled the course was because he was denied entry to the US as a result of his refusal to provide biometric data as part of post-9/11 US security measures. The resulting article is mostly a brief, simplistic version of his book Homo Sacer, but Agamben does imply that modern security and surveillance techniques are emerging as the new paradigm (though not to the extent of the camp) of the state of exception, in which the exception has become the rule:

There has been an attempt the last few years to convince us to accept as the humane and normal dimensions of our existence, practices of control that had always been properly considered inhumane and exceptional. Thus, no one is unaware that the control exercised 
by the state through the usage of electronic devices, such as credit cards or cell phones, has reached previously unimaginable levels. (Agamben 2004)

Electronic and biometric surveillance are the tactics through which the government is creating a space in which the exception is routine practice. The biopolitical implication of surveillance is the universalization of bare life: "History teaches us how practices first reserved for foreigners find themselves applied later to the rest of the citizenry" (ibid). These new control measures have created a situation in which not only is there no clear distinction between private and political life, but there is no fundamental claim, or right, to a political life as such - not even for citizens from birth; thus, the originary biopolitical act that inscribes life as political from birth is more and more a potential depoliticization and ban from the political realm.

We are all exposed to the stateless potentiality of a bare life excluded from the political realm, but not outside the violence of the law (and therefore still included): "states, which should constitute the precise space of political life, have made the person the ideal suspect, to the point that it's humanity itself that has become the dangerous class" (ibid). Making people suspects is equivalent to making people bare life - it is the governmental (a Foucauldian governmentality rather than an Agambenian sovereignty I would argue) production of a life exposed to the pure potentiality of the state of exception: "the sovereign ban, which applies to the exception in no longer applying, corresponds to the structure of potentiality, which maintains itself in relation to actuality precisely through its ability not to be” (Agamben 1994, 46). Surveillance is the technique that opens up this potentiality, which allows for the normalization of the exception. In this particular instance - i.e. biometric data collection and surveillance in the US - the state of exception as a permanent form of governmentality and the universalization of homines sacri has been brought into existence though the USA Patriot $\mathrm{Act}^{2}$ and the Patriot Act $\mathrm{II}^{3}$.

I have used the term 'potentiality' a number of times precisely to point to the state in which the citizens (or, more broadly, the population) of a number of countries find themselves. The potentiality I want to analyse can follow two directions: it is the potentiality to be stripped of citizenship, to be banned, to be abandoned to the law, and to be subjected to political violence, or it is the potentiality for the government to exercise violence and exceptional law upon the population. So, this potentiality can be both negative and positive. Although violence becomes indistinguishable from law - or, more specifically, indistinguishable from surveillance and control - in the state of exception, what needs to be emphasised is that it is not a power relation of pure violence, but rather, of potential violence. It is important, as Benjamin notes in "Critique of Violence", to understand that violence is a function of the power mechanisms of the government (although Benjamin would probably say 'sovereign'): “the law's interest in a monopoly of violence vis-à-vis individuals is not explained by the intention of preserving legal ends but, rather, by that of preserving the law itself; that violence, when not in the hands of the law, threatens it not by the ends that it may pursue but by its mere existence outside the law" (Benjamin 1933, 136). The state of exception arises when the population threatens to take violence away from the law - the population (rather than individuals per se) are regulated by surveillance methods, in order to ensure that the 'norm' of the law is not threatened; and for this norm to remain 'in force' an indefinite period of state of exception is often exercised, as we see with the example of the USA Patriot Act.

\section{The American State of Exception}

\footnotetext{
${ }^{2}$ USA PATRIOT Act stands for "Uniting and Strengthening America by Providing Appropriate Tools Required to Intercept and Obstruct Terrorism Act”, and was passed into law in the US only 45 days after $11^{\text {th }}$ September 2001.

3 The official name for the Patriot Act II is “Domestic Security Enhancement Act 2003”. This document was circulated as proposed legislation by former US Secretary General John Ashcroft on $10^{\text {th }}$ January 2003. Although the document has not been passed into law en bloc, parts of it have been couched in other legislation. For example, Bush signed a bill on $13^{\text {th }}$ December 2003 (the day Saddam Hussein was captured) providing the FBI with more surveillance and 'snooping' powers hidden as Section 374 of Intelligence Authorization Act for Fiscal Year 2004. Other parts of Patriot Act II have been passed under Senate Bills S.22, S.45, S.16, and S.89.
} 


\section{Surveillance and the External 'Threat'}

This politics of potentiality is created through the de facto 'laws' of state of exception legislation like the Patriot Act. Looking at actual parts of the Act, we can see that it exemplifies the state of emergency referred to by Agamben et al.; the 'normal' law of the state is not abolished but its "application is suspended" so that it still technically "remains in force” (Agamben 2003, 31). As such, the suspension of the normal application of the law is done "on the basis of its right of self-preservation" (Schmitt 1985, 12), so that the exception is that which must produce and guarantee the norm. Obviously then the state of exception is not intended to be anything more than a temporary safeguarding of normal law. In fact, there can be no 'normal' law without the state of exception: "the state of exception allows for the foundation and definition of the normal legal order" (Agamben 1999, 48). The use of the state of emergency to protect the normality of the legal order dates back at least as far as the Roman Empire. Whenever the Senate believed the state to be in danger, they could implement the iustitium, which allowed for the consuls "to take whatever measures they considered necessary for the salvation of the state" (Agamben 2005, 41).

Looking back at the Judean Roman camp example, the detention of the Jews could be seen as enacted during an iustitium when Jewish rebelliousness was endangering the newly acquired Roman providence of Judea. The iustitium, as with other examples of the state of exception, is a void in which the "suspension of the law" creates a zone that evades all legal definition. Thus, the state of exception is neither within nor outside of jurisprudence - it is "situated in an absolute non-place with respect to the law" (ibid, 50-51). This 'non-place', however, also has literal geographic implications - the 'place' of the camp is no longer necessary for creating bare life. Rather, the mutually operative surveillance and state of exception allow for a city-camp, which maintains control and suspicion over a population without necessitating borders. But, we must distinguish - and this is relevant for the Roman camp example between the functionality and mechanization of camps (see abstract). For example, the Roman camp, prison, border camp, work camp, etc. all have a different functionality - from the suppression of a rebellion to idle detention - but the mechanizations they employ to carry out this functionality are the same - to monitor and maintain control over a given population by creating bare life (the reason the population is in a camp in the first place is surprisingly irrelevant). Although the functionality of camps may differ, I want to emphasize that the mechanizations of power will always employ a structure of surveillance; this is the link between ancient and modern camps.

Moving away from ancient examples of the state of exception and looking at the current American judicial-political situation, Agamben's central argument in Homo Sacer and State of Exception is that modern politics are defined by the permanence of a state of exception in which the exception becomes the rule, or the norm. An example of this exception-as-the-rule can be seen in an American 2006 CRS Report for Congress on national emergency powers: "those authorities available to the executive in time of national crisis or exigency have, since the time of the Lincoln Administration, come to be increasingly rooted in statutory law" (Relyea 2006, 2, author’s italics). It continues:

Under the powers delegated by such statutes [constitutional law, statutory law, and congressional delegations], the President may seize property, organize and control the means of production, seize commodities, assign military forces abroad, institute martial law, seize and control all transportation and communication, regulate the operation of private enterprise, restrict travel, and, in a variety of ways, control the lives of United States citizens. (ibid, 4, author's italics).

This report alludes to biopolitical powers for one, but also the ways in which the state of emergency is implemented through a variety of statutes, and not instituted as one bill or act that can be in or out of force en bloc. Rather, it is becoming more difficult to identify juridical documents that provide state of exception powers that are clearly distinguishable from 'normal' law. The Patriot Act, to be sure, is clearly identifiable from 'normal' US law, but The Domestic Security Enhancement Act 2003 was not passed under that name (nor under the alias 'Patriot Act II'), but was tacked on to other Senate Bills 
piecemeal. For example, some enhanced surveillance measures were not passed under the Patriot Act, but were passed into US Code - under title 50, chapter 36, subchapter I, § 1802 of the US Code: "Notwithstanding any other law, the President, through the Attorney General, may authorize electronic surveillance without a court order under this subchapter to acquire foreign intelligence information for periods of up to one year". So, 'snooping' surveillance tactics will still be part of 'normal' law even if the Patriot Act is not renewed; this is what Agamben means when he writes of the "permanent state of emergency" (Agamben 2005, 2).

There are a few sections of the Patriot Act that are worth discussing in order to demonstrate the modern state of exception, as well as its link to surveillance and the camp. Under Section 412 of the Act, entitled "Mandatory detention of suspected terrorists", the Attorney General has the power "to certify that an alien meets the criteria of the terrorism grounds of the Immigration and Nationality Act, or is engaged in any other activity that endangers the national security of the United States, upon a 'reasonable grounds to believe' standard, and take such aliens into custody". The Attorney General must review the detention every six months and determine if the alien is to remain in detention because of a continued risk to security. But what remains ambiguous, and allows for the indistinction between law and violence and between police and sovereignty, is this "reasonable grounds to believe standard". Suffice it to say, without going into greater depth, this 'standard' is grounds for racial profiling and the detention of political opponents. Also, the detention of aliens on a 'belief' is the production of bare life, since it is the stripping of rights without reference to a violation under 'normal' law; in other words, these "suspected terrorists" are detained without having done anything wrong, but must be situated in the state of exception camp for those who may threaten the 'normal' force of the law - this is the aforementioned void, or 'nonplace', of the law. Since these aliens cannot be detained under the normal law, a camp of suspects must emerge in a national security emergency.

What is also telling about this Act is that the ten Titles may be seen as different governmental tactics, networked in one state of emergency act; Titles include, "Enhancing Domestic Security against Terrorism", "Protecting the Border", "Strengthening the Criminal Laws against Terrorism", and "Increased Information Sharing for Critical Infrastructure Protection". Foucault would be quick to point out that this Act characterizes the population conducting tactics that define governmentality: policing, disciplining, and security. However, Title II, "Enhanced Surveillance Procedures", not only becomes implicit in many of the other areas of the act that discuss "intelligence" and "security", but also allows the Act to go beyond the protection of the 'norm' in a sovereign nation-state through foreign surveillance provisions. Section 214 functions in collaboration with and amends several parts of the Foreign Intelligence Service Act 1978 (FISA) in order to allow for international surveillance activities in order identify suspected terrorists: during periods of emergency (i.e. state of exception), the US invests itself with the power to collect "foreign intelligence information not concerning a United States person or information to protect against international terrorism or clandestine intelligence activities” (Sec. 214(b) (1)).

The detention and surveillance of aliens continues though other mechanisms of jurisprudence, which, as mentioned, are becoming normalised through bills, acts, etc. that are not designed as state of emergency 'law' per se. On $13^{\text {th }}$ November 2001, George W. Bush issued a military order for the "Detention, Treatment, and Trial of Certain Non-Citizens in the War Against Terrorism"; by 'certain' this order means anyone "believed" to be associated with al Qaida (PoTUS, 2001). Like with Section 412 of the Patriot Act, suspected terrorists are to be detained without a court order. Similarly, under the Terrorism Act 2000 in the UK, "A constable may arrest without a warrant a person whom he reasonably suspects to be a terrorist" (Section 41(1)). As with the US, any person detained under this Act can remain in detainment following and pending a review (Schedule 8, Part II).

\section{The Disappearance of Citizenship ${ }^{4}$}

\footnotetext{
${ }^{4}$ See: Virilio 2005, 165.
} 
What we have been discussing thus far applies to the "indefinite" and "mandatory" detention of aliens, but the Patriot Act and the Terrorism Act contain various sections on increased surveillance measures that target aliens and native citizens alike. These surveillance activities include the collection of DNA from anyone detained for any offence or suspected of terrorism, phone taps, wiretaps for electronic communications, the collection of individual library records (Section 215; this Section in particular has received heavy criticism and debate), the collection of banking and financial records, and other indirect surveillance methods, such as the collection of biometric data at US borders (as Agamben experienced).

However, these universal surveillance methods become much more significant when we consider the proposed increased governmental powers outlined in the Domestic Security Enhancement Act 2003 (alias, Patriot Act II). Under Section 501 of Patriot Act II the "mandatory dentition" of aliens suspected of terrorism extends to include Americans, who can also be stripped of their citizenship and made stateless detainees. As Gore Vidal remarks, "under Patriot Act I only foreigners were denied due process of law as well as subject to arbitrary deportation...Patriot Act II now includes American citizens in the same category, thus eliminating in one great erasure the Bill of Rights” (Vidal 2003). Section 501, "Expatriation of Terrorists", of the Act states:

This provision (i.e. Section 501) would amend 8 U.S.C. § 1481 to make clear that, just as an American can relinquish his citizenship by serving in a hostile foreign army, so can he relinquish his citizenship by serving in a hostile terrorist organization. Specifically, an American could be expatriated if, with the intent to relinquish nationality, he becomes a member of, or provides material support to, a group that the United States has designated as a "terrorist organization," if that group is engaged in hostilities against the United States.

With the power proposed in this section of the Patriot Act II, the government would be able to produce bare life with both aliens and American citizens - "a process leading to the disappearance of citizenship by transforming the residents into 'foreigners within', a new sort of untouchable [homo sacer], in the transpolitical and anational state where the living are nothing more than the "living dead'” (Virilio 2005, 165).

We have seen how a permanent state of emergency creates a situation in which foreign residents or visitors can be detained without a court order for an indefinite period of time; even greater governmental powers are now aiming at expanding this exposure to the pure power of the juridical-political system to citizens as well. Citizenship and political significance are becoming less fundamental and inalienable rights and more categorizations that are only maintained though blind adherence to so-called democratic polices, which look more and more like a dictatorial structure (see: Arendt 1973).

What should also be mentioned is the production of bare life in foreign states; or, conversely, the loss of political rights to another state power within one's own country. The power to detain and expose individuals to pure violence and even death is characteristic of the CIA's and MI5's borderless security, policing and surveillance mechanisms, which becomes more evident with the Patriot Act and FISA. This may be seen as grounds for a debate between sovereignty and governmentality. Is sovereignty concerned, above all, with the territorial nation-state, as Foucault argues (Foucault 2007, 14)? Or, is sovereignty more accurately defined as that which decides on the exception, as Schmitt and Agamben maintain? Neither of these questions can be properly answered until we understand the relations between sovereignty and foreign states. That is to say, is sovereignty only possible in a contained nation-state, or is it something broader that can be applied to foreign nations and even to the point of being able to declare a state of exception in a foreign land? But if this latter situation is possible - the suspension of other sovereigns' law - maybe it is something that should, as Foucault insists, be called 'governmentality'. What should be understood as common to both conceptions of sovereignty and governmentality, however, is the production of camp, in which the state of exception reaches its ultimate 
realization. It should be clear that the Patriot Act and other juridical-political provisions precondition and allow for the continued existence of the camp.

\section{Conclusion}

The difficulty with theorizing surveillance is that it cannot be done positivistically - it needs to be situated within a state system that has a biopolitical relationship with the population through a network of various techniques and conducting mechanisms. Failing to do so will result in a superficial study of surveillance that neglects the crux of governmental tactics. On the other hand, accounting for the various relations that condition and require surveillance can make theoretical examinations appear as though they are not 'about' surveillance. But this is certainly not the case.

Before we can even ask why a state uses surveillance mechanisms, we need to define what state structure we are talking about. Following Foucault, governmentality best describes our current political situation, as it is above all concerned with managing the internal structure of the state according to a biopoliticization of the population, rather than maintaining the power over life and death, as is characteristic of sovereign politics. Governmentality is literally an 'art' of governing, in which the population is 'conducted' through various relations and tactics employed by the state, such as institutions, security, statistics, and surveillance. So, governmentality is the structure in which surveillance can operate as one of the arms of state power.

When we move towards the juridical-political situation of the state of exception, we see another area in which surveillance plays a crucial biopolitical role. The use of exceptional legal measures in order to protect the 'normal' force of law is what defines the state of exception. The 'normal' law that is suspended is often that which guarantees the rights and the citizenship of foreign and national citizens; thus, under an exceptional juridical situation, individuals with no political significance are produced: bare life. The USA Patriot Act (among other documents) embodies this loss of rights, production of bare life, and increased surveillance based on a perceived national threat. The state of exception, Agamben argues, is becoming more and more the normal course of politics - this is nowhere more exemplary than in the camp. The camp is the place where bare life is produced and the exception becomes the rule.

Yet, the Roman camp in Judea shows us that the emersion of surveillance in a camp-'state of exception'territory structure is nothing new. What is primarily 'modern' is not biopolitics (Foucault) or the camp (Agamben), but the governmental control of the disappearance of citizenship. With digital technology, the erasure of a definite 'here' or 'there' means that the localised camp is no longer a paradigmatic 'place' where the limit of the state of exception is realised; rather, the non-place of a population in constant movement is what defines the new non-place of the city camp. Thus, surveillance is deeply imbedded in and necessary for the governmental system that seeks to be instantly aware of any potential threats to the state so that it can quash those threats by depoliticizing 'dangerous' portions of the population and exposing them to the pure potentiality of the 'management' of life. 


\section{References}

Agamben, Giorgio. 1998. Homo Sacer: Sovereign Power and Bare Life. Trans. Daniel Heller-Roazen. Stanford: Stanford University Press.

Agamben, Giorgio. 2004. No to Bio-political Tattooing. Le Monde. 10 January. Trans. Leslie Thatcher for Truthout. http://www.truthout.org/article/le-monde-no-bio-political-tattooing (accessed 01/12/2008).

Agamben, Giorgio. 1999. Remnants of Auschwitz: The Witness and the Achive. Trans. Daniel Heller-Roazen. New York: Zone Books.

Agamben, Giorgio. 2005. State of Exception. Trans. Kevin Attell. Chicago: University of Chicago Press.

Arendt, Hannah. 1998. The Human Condition. Second Edition. Chicago: University of Chicago Press.

Arendt, Hannah. 1973. Origins of Totalitarianism. Trans Richard and Clara Winston. Pennsylvania: Harvest.

Foucault, Michel. 1977. Discipline and Punish: The Birth of the Prison. Trans. Alan Sheridan. London: Penguin.

Foucault, Michel. 1990. The History of Sexuality Volume 1. Trans. Robert Hurley. London: Penguin.

Foucault, Michel. 2000. Power: Essential Works of Foucault 1954-1984 Volume 3. Ed. James D Faubion. London: Penguin.

Foucault, Michel. 2007. Security, Territory, Population: Lectures at the Collège de France 1977-1978. Ed. Michel Senellart, trans. Graham Burchell. New York: Palgrave.

President of the United States (PoTUS) (2001) Military Order: (13 November 2001) Detention, Treatment, and Trial of Certain Non-Citizens in the War Against Terrorism. http://jurist.law.pitt.edu/terrorism/terrorismmilord.htm (accessed $01 / 12 / 2008)$.

Relyea, Harold C. 2006, updated 2007. National Emergency Powers. Order Code 98-205 GOV, 13 November 2006. Washington DC: Congressional Research Services. http://www.fas.org/sgp/crs/natsec/98-505.pdf (accessed $01 / 12 / 2008)$

Schmitt, Carl. 1985. Political Theology: Four Chapters on the Concept of Sovereignty. Trans. George Schwab. Bakersville: MIT Press.

United Kingdom. 2000. Terrorism Act 2000. 20 July. London: TSO.

United States. 2001. Department of Homeland Security. Uniting and Strengthening America by Providing Appropriate Tools Required to Intercept and Obstruct Terrorism (USA Patriot Act) Act of 2001. 26 October. Washington DC: GPO.

United States. Office of the Attorney General. 2003. The Domestic Security Enhancement Act 2003 (also known as Patriot Act II). 9 January. Washington DC: GPO.

Vidal, Gore. 2003. We Are The Patriots. The Nation 273(1): 2.

Virilio, Paul. 2005. Negative Horizon. Trans. Michael Degener. London: Continuum.

Virilio, Paul. 1997. Open Sky. Trans. Julie Rose. London: Verso.

Yekutieli, Yuval. 2006 Is Somebody Watching You? Ancient Surveillance Systems in the Southern Judean Desert. Journal of Mediterranean Archaeology 19(1): 65-89. 